\title{
Pedagogy and Information Technology Integration, As Strategies for Improving Academic Performance in Stem Subjects: A Critical Literature Review
}

\author{
Dr. Veronica Kaluyu ${ }^{1}$ \\ Chandaria School of Business \\ United States International University-Africa \\ vkaluyu@anu.ac.ke \\ Dr. Judah M. Ndiku \\ Masinde Muliro University of Science and Technology \\ P. O Box 190, Kakamega - 50100 \\ jndiku@mmust.ac.ke
}

\begin{abstract}
Globally, the teaching of STEM subjects has been construed as a plausible solution to solving societal problems ranging from economic to social development issues. In order to realize these benefits, there is need to focus on the pedagogy in teaching of STEM subjects. Besides in $21^{\text {st }}$ Century use of IT has become both enabler and a driver of every part of life including education. As such this study purposes to explore and synthesize major trends of research on stem subjects' pedagogy and IT integration and academic performance. The systematic critical review methodology for this study included perusal of quality journal articles related to topic of study in the last three years. However, in cases of absence of more recent studies, collection of information from previous years was allowed. The main search key themes included: Pedagogical beliefs and attitudes, IT access and integration, Skills capacity interventions, Cloud digital content and academic and Performance in STEM Subjects The selected journals include but not limited to Emerald, Taylor and Francis, JSTOR, EBSCOhost and Wiley Online.

Study findings show varying propositions regarding teacher pedagogy aspects and integration of IT in STEM subjects. Particularly teacher beliefs and attitudes seem to have implication on probability of IT integration in STEM teaching; while IT access, skills capacity interventions, access to cloud digital content pose a challenge in teachers' pedagogical practices which in turn affect the learner performance. Despite the comprehensive literature search and review across geographical regions within limits of time and access, it is clear that the study findings prepare ground for further research and possibility of capacity building interventions.
\end{abstract}

KEY WORDS: Pedagogical beliefs, IT access and integration, Skills capacity interventions, Cloud digital content and academic Performance in STEM Subjects

DOI: $10.7176 / \mathrm{JEP} / 11-21-21$

Publication date:July 31 st 2020

\section{INTRODUCTION}

Pedagogy comprises teachers' ideas, beliefs, attitudes, knowledge and understanding about the curriculum, the teaching and learning process and their students, and which impact on their 'teaching practices', that is, what teachers actually think, do and say in the classroom (Black \& William, 2018; Alexander, 2009). According to (Bhowmik et al., 2013), Serikov, (2019);Pedagogy is the art and science of teaching. Effective teachers use an array of teaching strategies because there is no single, universal approach that suits all situations. Different strategies are used in different combinations with different groups of students to improve their learning outcomes. Some teaching strategies are better suited to teaching certain skills and fields of knowledge than are others. As such, Pedagogy, being the art of teaching, involves conveyance of knowledge and skills in ways that students can understand, remember and apply. It also entails interactions between teachers, students, the learning environment and the learning tasks. Arguments in the 21st Century ( Hanif et.al 2019; Fakomogbon, Bolaji , 2017; De Jong, 2019) purport that relevant teaching pedagogy should include: teaching contextually, use of inter-disciplinary approaches, Work collaboratively with students, Use project based approaches, foster problem solving, and transparent assessment, develop thinking skills and build technological, information and media competencies (Maluleke, 2019; Mua,2017)

In Africa, strategic response to teaching of STEM subjects with vigilance of integration of Information Communication Technology has been on course (Barakabitze et al., 2019a) but with challenges related to teacher attitudes, believes and perceptions, the STEM necessary infrastructure, technology access and the teacher skill to integrate it in teaching (Guler et al., 2019) In East Africa, several initiatives have been explored in effort to revamp 
the teaching of STEM subjects but not without challenges related to teacher skills and preparedness; poor infrastructure for teaching STEM subjects and low level of Technology access (Joubert et al., 2018) In Kenya, there is evident struggle with teaching of STEM subjects despite efforts by government to train primary and secondary school teachers; case in point is the baseline survey results showing poor performance in these subjects in Kakamenga, Vihiga and Kisumu counties ((Ndiku et al., 2020)

\section{PROBLEM STATEMENT}

Despite capacity building efforts and interventions in pedagogy related to teaching of STEM subjects in Kenya such as SMASSE,INSET(Joubert et al., 2018) unsatisfactory performance has been registered in these subjects in National examination results(Ochich et al., 2018) .For instance, in 2017; 545,014 candidates sat for Biology but only 1,503 scored $\mathrm{C}+$ and above; in Mathematics out 609,495 candidates only 3,926 scored $\mathrm{C}+$ and above. In Chemistry 606,006 candidates sat for the exam but only 54,925 scored C+ and above while in 2018 in Mathematics, out of 653,549 candidates 98,219 scored C+ and above; Biology out of the 584,924 candidates only 33,126 scored $\mathrm{C}+$ and above; while in Chemistry out of the 650,898 candidates who sat for the exam only 73,566 scored $\mathrm{C}+$ and above (Ndiku et al., 2020).Further, integration of ICT use in education has been propelled through National policy for using ICT; Particularly, through programs such as Computers for Schools in Kenya, ICT equipment for schools, NEPAD e-schools initiative and School Broadcasting which amidst a myriad of challenges have sluggishly met the set objectives one of which is integration of IT in teaching and learning (Barakabitze et al., 2019b).

There is extensive research in the area of STEM education and integration of ICT in schools across world divides; studies on Pedagogical Beliefs of Teachers on Use of ICT Integration in Teaching of STEM Subjects ((Margot \& Kettler, 2019; Madani \& Forawi, 2019; (Kurup et al., 2019) point to absolute belief and intention of teachers to acquire the necessary skills through training and belief that in-service professional training will increase their capacity to positively influence learner performance. Additional research on Teachers' ICT Skills Gap on Use of ICT Integration in Teaching of STEM (Kurup et al., 2019; Gardner et al., 2018; Hennessy et al., 2010))Subjects show that skills gap exists among teachers across continents in terms of ICT skills and integration in their teaching pedagogy and that teacher training does not keenly focus on computer skills and especially those related to STEM teaching. On the other hand, challenges and barriers to appropriate STEM subjects pedagogy, skills and competences are associated with teachers' access to ICT (Mua Rodanny Kennah, 2017; Ullah et al., 2019; Ishaq et al., 2020) and limited access to digital content as well as iCloud repositorios ( (Walker, Cammy, Ellis, \& Seibert, 2011; Bamgbade et al., 2015; Wangila, 2014) ; Durodolu \& Mojapelo, 2020; Tahir \& Yucel, 2019) In a nutshell, research relating to pedagogical issues and academic performance particularly in Kenya are insufficient; therefore, a study gap exists in this realm and hence this study's' intention is to bridge this study gap and provide interventions in terms of capacity building in pedagogy for STEM subject teachers in Kenya.

\section{PURPOSE OF STUDY}

The purpose of this study is to carry out a critical literature review on influence of STEM subject's pedagogy and IT integration on academic performance in Kenya. The study also purposes to pave way for empirical survey to inform capacity building interventions in STEM pedagogy among Secondary school teachers in selected counties in Kenya

\section{RESEARCH QUESTIONS}

Based on above background, ensuing questions that need to be addressed in order to unveil underlying problems and address this poor performance in Kenya entail:

1. Does pedagogical beliefs of teachers on use of IT integration in teaching of [STEM subjects] influence students' academic Performance?

2. To what extent does the teachers' IT skills gap on use of IT integration in teaching of

[STEM subjects] influence Students academic Performance?

3. Does teacher's plausible skills capacity interventions on the use of IT integration in the teaching of [STEM subjects] influence students' academic Performance? 
4. To what extent does access to IT in education on use of IT integration in the teaching of [STEM subjects] influence students' academic Performance?

5. Does availability of digital content in the cloud on the use of IT integration in the teaching of [STEM subjects] influence students' academic Performance?

\section{THEORETICAL ANALYSIS}

Mainly, studies focusing on pedagogy have reported use of traditional psychology theories related to behaviorism, and constructivist theories. However, (Hunter, 2017) emphasizes on use of High Performance Computing (HPC) as a fresh conceptual framework for technology integration that has taken the TPACK framework and built on it from research on exemplary teachers' knowledge of technology integration in Australian primary and secondary school classrooms ((Hunter, 2017; Hewes, 2016; Littlejohn, 2016). The framework's five conceptions of theory, creativity, public learning, life preparation and contextual accommodations form an evidence-based scaffold that reflects these teachers' knowledge of technology integration in action. Each conception is underpinned by themes of pedagogical strategies and students' learning processes as depicted in Table1.

Table 1. Twenty-two themes of student learning processes and teaching strategies that underpin the HPC conceptions.

\begin{tabular}{|c|c|c|c|c|}
\hline $\begin{array}{l}\text { Theory-driven tech- } \\
\text { nology practice }\end{array}$ & $\begin{array}{l}\text { Creativity for learning } \\
\text { through technology }\end{array}$ & $\begin{array}{l}\text { Public learning } \\
\text { through technology }\end{array}$ & $\begin{array}{l}\text { Life preparation } \\
\text { using technology }\end{array}$ & $\begin{array}{l}\text { Contextual accom- } \\
\text { modations using } \\
\text { technology }\end{array}$ \\
\hline $\begin{array}{l}\text { Technology drives con- } \\
\text { struction of learning }\end{array}$ & $\begin{array}{l}\text { Technology boosts } \\
\text { creativity }\end{array}$ & $\begin{array}{l}\text { Technology scaffolds } \\
\text { performance }\end{array}$ & $\begin{array}{l}\text { Technology operation- } \\
\text { alises the real world }\end{array}$ & $\begin{array}{l}\text { Technology remains } \\
\text { personal and profes- } \\
\text { sional }\end{array}$ \\
\hline $\begin{array}{l}\text { Technology enhances } \\
\text { purposeful teaching }\end{array}$ & $\begin{array}{l}\text { Technology creates } \\
\text { opportunities for } \\
\text { production }\end{array}$ & $\begin{array}{l}\text { Technology enhances } \\
\text { outcomes }\end{array}$ & Technology gives voice & $\begin{array}{l}\text { Technology changes } \\
\text { time }\end{array}$ \\
\hline $\begin{array}{l}\text { Technology focuses } \\
\text { planning }\end{array}$ & $\begin{array}{l}\text { Technology unleashes } \\
\text { playful moments }\end{array}$ & & $\begin{array}{l}\text { Technology means } \\
\text { ownership and } \\
\text { possibility }\end{array}$ & $\begin{array}{l}\text { Technology nurtures } \\
\text { community }\end{array}$ \\
\hline $\begin{array}{l}\text { Technology enriches } \\
\text { subject matter }\end{array}$ & $\begin{array}{l}\text { Technology supports } \\
\text { values }\end{array}$ & & $\begin{array}{l}\text { Technology reveals } \\
\text { effectiveness }\end{array}$ & $\begin{array}{l}\text { Technology defines the } \\
\text { game }\end{array}$ \\
\hline $\begin{array}{l}\text { Technology promotes } \\
\text { reflective learning }\end{array}$ & $\begin{array}{l}\text { Technology differenti- } \\
\text { ates learning }\end{array}$ & & & \\
\hline \multicolumn{5}{|l|}{$\begin{array}{l}\text { Technology shifts con- } \\
\text { versation and thinking }\end{array}$} \\
\hline $\begin{array}{l}\text { Technology engages } \\
\text { students in authentic } \\
\text { ways }\end{array}$ & & & & \\
\hline
\end{tabular}

Source Hunter (2017)

On the other hand, studies focusing on IT integration to improve learner performance have adopted the Theory of reasoned Action( TRA) by Ajzen and Fishbein (1973), as cited by (Kilty, 1978) Technology Adoption Model (TAM) by Davis in 1989 ; and has been used to explore the features that inform user acceptance of a digital library system implementation (Miller \& Khera, 2010). TAM2 theorizes that external factors are critical to the perceived usefulness and thus the predictive power of the TAM framework. User acceptance of information Technology (UTAUT) by Vankatesh et al (2003) has also been used to explain Teacher Technology integration in practice.

\section{METHODOLOGY}

\section{Data Collection}

Data collection was systematically done from various data bases.

\subsubsection{Database}

The study focused in search of databases known for education, Library and information technology: Elsevier Science consisting of Computers \& Education, JSTOR consisting Journal of Educational Technology \& Society, Science Direct consisting of Computers in Human Behavior, SAGE Journal Online, Wiley online library consisting Journal of Computer Assisted Learning, EBSCOhost, Taylor and Francis. However, among these, five were selected for data analysis and these include: Emerald, JSTOR, Wiley online, EBSCOhost and Taylor \& Francis. 


\subsubsection{Keywords and Search Terms}

The key words and search terms used in the study include: Pedagogical beliefs, IT access and integration, Skills capacity interventions, Cloud digital content and academic Performance in STEM Subjects. These key words were also searched in accordance to study objectives combinations as follows: Pedagogical beliefs of teachers on use of IT integration in teaching of [STEM subjects] and students' academic Performance; teachers' IT skills gap on use of IT integration in teaching of [STEM subjects] and Students academic Performance; the teachers' IT skills gap on use of IT integration in teaching of [STEM subjects] and Students academic Performance; teacher's plausible skills capacity interventions on the use of IT integration in the teaching of [STEM subjects] and students' academic Performance; access to IT in education on use of IT integration in the teaching of [STEM subjects] and students' academic Performance and availability of digital content in the cloud on the use of IT integration in the teaching of [STEM subjects] influence students' academic Performance.

Although the search result produced a large number of studies, only the articles that were screened by the inclusion and exclusion criteria were selected for this systematic review.

\section{Selection Criteria}

\begin{tabular}{|l|l|}
\hline Inclusion Criteria & Exclusion Criteria \\
\hline $\begin{array}{l}\text { Factors related to pedagogy in STEM and IT } \\
\text { integration: Pedagogical beliefs, IT access and } \\
\text { integration, Skills capacity interventions, Cloud } \\
\text { digital content. }\end{array}$ & $\begin{array}{l}\text { Factors other than the indicated pedagogical } \\
\text { aspects were excluded in the study }\end{array}$ \\
\hline $\begin{array}{l}\text { Empirical studies related to pedagogy in STEM } \\
\text { subjects and IT integration }\end{array}$ & $\begin{array}{l}\text { Other empirical studies related to STEM but } \\
\text { outside pedagogy were excluded }\end{array}$ \\
\hline $\begin{array}{l}\text { Time period 2017-2020; cases of lack of more } \\
\text { recent studies allowed for some beyond the stated } \\
\text { period }\end{array}$ & $\begin{array}{l}\text { Time periods beyond five years and backwards } \\
\text { were excluded; But only accepted in situation of } \\
\text { lack more recent studies on a particular construct. }\end{array}$ \\
\hline $\begin{array}{l}\text { Studies with clear abstract and quality study } \\
\text { methodology }\end{array}$ & $\begin{array}{l}\text { Studies without clear abstract and sketchy study } \\
\text { methodology }\end{array}$ \\
\hline
\end{tabular}

\subsubsection{Data Extraction}

An excel data sheet was prepared for data mining. Each paper was analyzed for the following data: general information including source and year of publication, country/region/continent, study design, theoretical base, and sample size; result and research reliability.

Table 1

\begin{tabular}{|ll|}
\hline Data base & No. of studies \\
\hline EMRALD & 100 \\
\hline EBSCOhost & 60 \\
\hline JSTOR & 25 \\
\hline WILEY ONLINE & 150 \\
\hline TAYLOR \& FRANCIS & 165 \\
\hline TOTAL & 500 \\
\hline
\end{tabular}

The data analysis shows that a total of 500 studies from five databases where reviewed and based on key search words, most of the studies were found in Taylor and Francis while the least were reviewed from JSTOR data base. Emerald data base had 100 relevant studies. Therefore, the studies reviewed emanated largely from Taylor and Francis, Wiley online and Emerald data base all of which are reputable databases with quality research. This information is illustrated in Figure 1. 


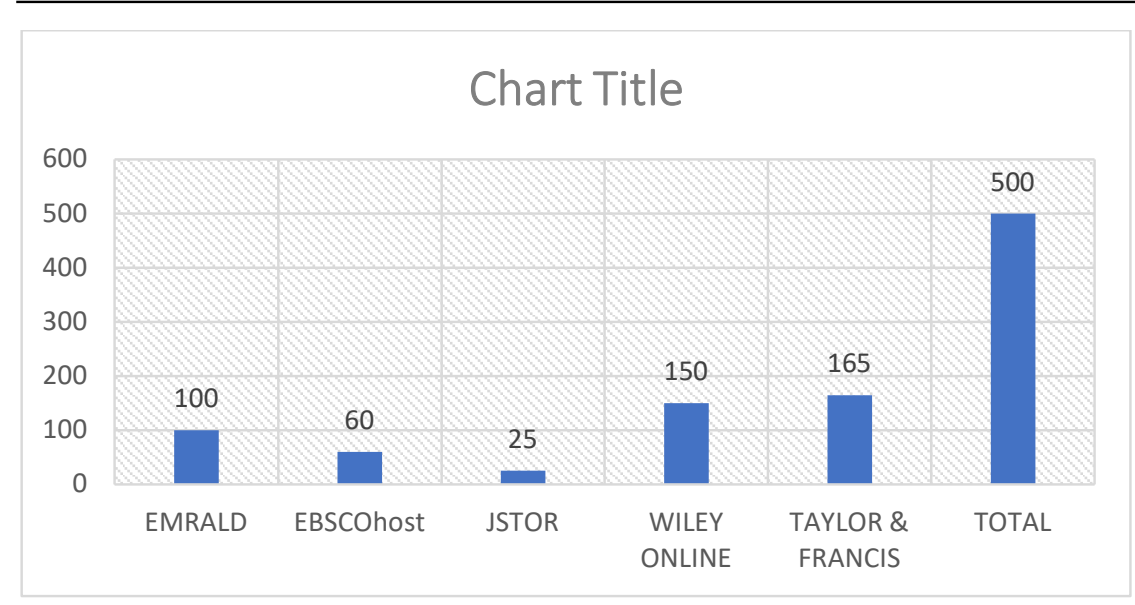

Figure 1

\subsubsection{Data Analysis}

Data analysis was categorically done along the key search words and the associated study objectives. The results of the study are presented in the next session

\section{RESULTS}

\subsection{Geographic Distribution of the Selected Studies}

The study also analyzed the geographical distribution of related studies per continent. Results show that most of studies were from the America, followed by Europe and least in Africa.

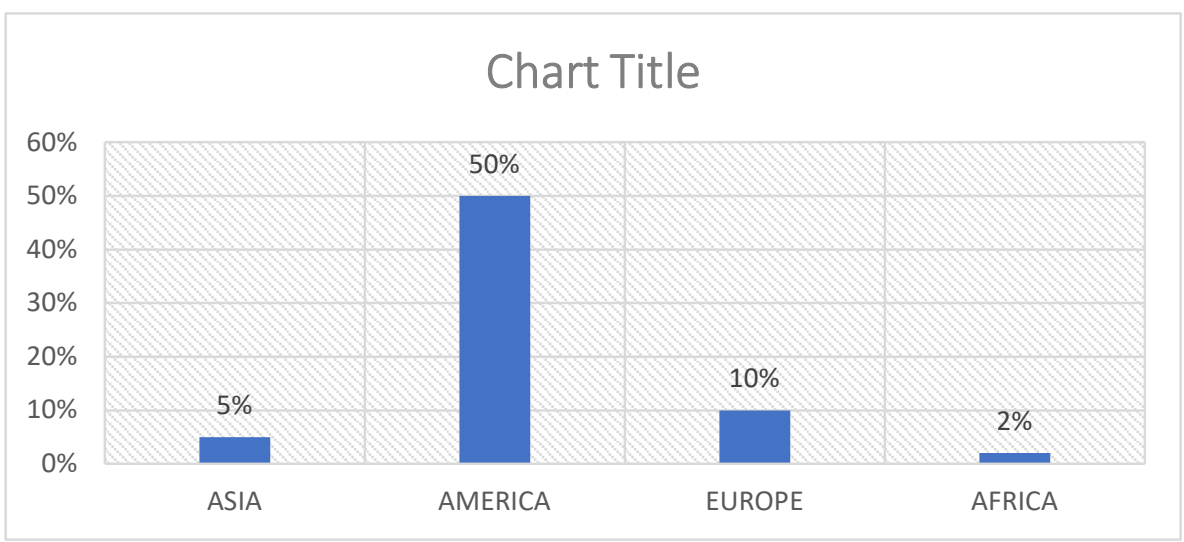

Figure 2

Figure 2 illustrates that there was minimal research related to key search words, published in these reputable journals from Africa and Asia.

3.2. Teachers' Pedagogical beliefs on use of IT integration in teaching of [STEM subjects] and influence on students' academic Performance

Assessment of specific studies relevant to access to digital books and reading outcomes, portray that most of the studies were from Wiley online and Taylor and Francis which are reputable data bases. Table 2 and figure 2 illustrate these results 
Table 2

\begin{tabular}{ll}
\hline Data Base & No. of selected Articles \\
\hline EMRALD & 80 \\
EBSCOhost & 50 \\
JSTOR & 5 \\
WILEY ONLINE & 100 \\
TAYLOR \& FRANCIS & 200
\end{tabular}

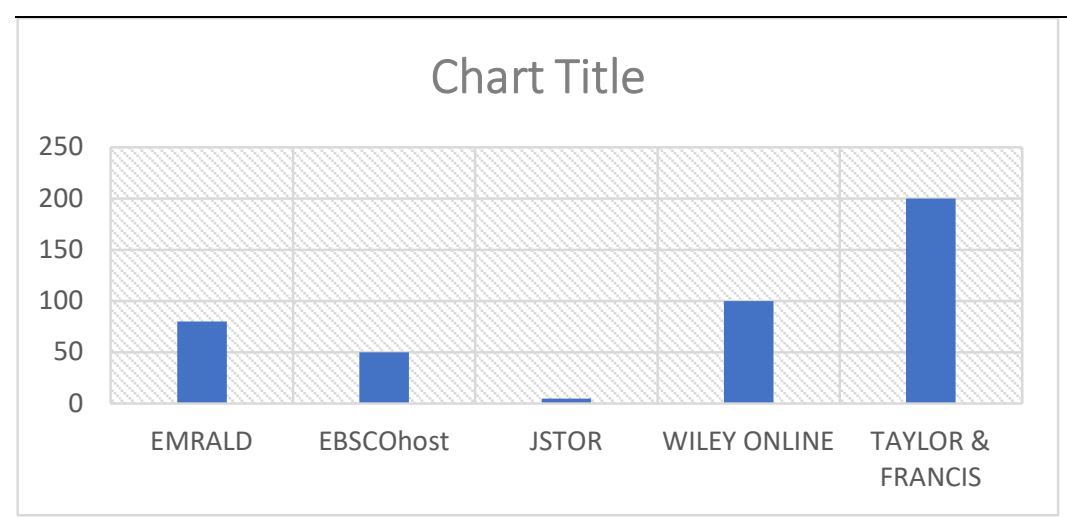

Figure 3

\section{Summary of Key Findings}

Some key studies illustrating key findings and ensuing study and intervention area gaps were summarized as follows:

\begin{tabular}{|c|c|}
\hline \multicolumn{2}{|c|}{$\begin{array}{l}\text { Teachers' Pedagogical beliefs on use of IT integration in teaching of [STEM subjects] and influence on students' academic } \\
\text { Performance }\end{array}$} \\
\hline Study & Key findings \\
\hline Eickelmann \& Vennemann,2017 & $\begin{array}{l}\text { Pedagogical beliefs of teachers on use and integration of ICT in teaching of STEM subjects is } \\
\text { likely to influence their perceptions and practice whereby negative beliefs may also negatively } \\
\text { affect learners' education outcome }\end{array}$ \\
\hline Bell, (2016) & $\begin{array}{l}\text { Teacher's perception of STEM, their personal knowledge, and understanding of that knowledge, is } \\
\text { intrinsically linked to the effectiveness of STEM delivery in their own classroom practice. }\end{array}$ \\
\hline Margot \& Kettler, 2019 & $\begin{array}{l}\text { Teachers, as important persons within a student's talent development, hold prior views and } \\
\text { experiences that will influence their STEM instruction }\end{array}$ \\
\hline Polgampala \& Shen, 2016 & $\begin{array}{l}\text { Lack of methodology, strategies and technology were some of the teacher perceptional challenges } \\
\text { in this study }\end{array}$ \\
\hline Leem and Sung (2019) & $\begin{array}{l}\text { Teachers' beliefs were consistently revealed the five factors of immediacy, interest, interactivity, } \\
\text { instability and inconvenience; teachers' beliefs that SMDs are unstable or uncomfortable can be the } \\
\text { main barrier to the use of technology in the classroom. }\end{array}$ \\
\hline Kurup et al., (2019) & $\begin{array}{l}\text { Pre-service teachers do not have strong understanding; however, they have strong beliefs and } \\
\text { intentions to teach STEM in their future career. }\end{array}$ \\
\hline Tsai and Tsai (2019) & $\begin{array}{l}\text { This study also found that the teachers who had more constructivist perceptions of teaching using } \\
\text { mobile devices, such as facilitating students' understanding in a convenient way or supporting } \\
\text { student learning in a more active way, appeared to attain better quality technology integration in } \\
\text { their lesson plans than those teachers with traditional conceptions }\end{array}$ \\
\hline $\begin{array}{l}\text { Chisango, Marongwe, Mtsi and } \\
\text { Matyedi (2020) }\end{array}$ & $\begin{array}{l}\text { The study found that the teachers had a positive attitude towards the adoption of technologies and } \\
\text { were ready to integrate ICTs in teaching and learning but they lacked the requisite ICT skills }\end{array}$ \\
\hline Gap & $\begin{array}{l}\text { Studies seem to converge that teachers have positive attitude towards IT integration in teaching, but } \\
\text { gap exists in access to relevant training in their professional training; and access to necessary IT } \\
\text { infrastructure. }\end{array}$ \\
\hline
\end{tabular}




\subsection{Teachers' IT skills gap on use of IT integration in teaching of [STEM subjects] and influence on Students academic Performance}

Assessment of specific studies relevant to digital library subscription costs and reading outcomes, portray that most of the studies were from Wiley online and Taylor and Francis which are quality research data bases. Table 3 and figure 3 illustrate these results

Table 3

\begin{tabular}{l|l} 
Data Base & No. of selected Articles \\
\hline EMRALD & 30 \\
\hline EBSCOhost & 50 \\
\hline JSTOR & 5 \\
\hline WILEY ONLINE & 120 \\
\hline TAYLOR \& FRANCIS & 150 \\
\hline & \\
\hline
\end{tabular}

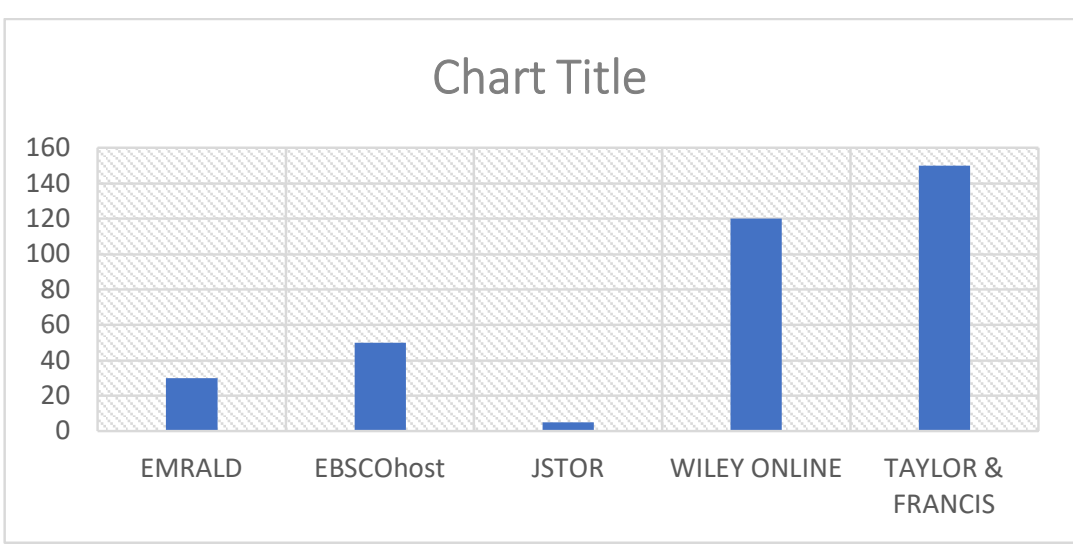

Figure 4

\section{Summary of Key Findings}

Some key studies illustrating key findings and ensuing study and intervention gaps were summarized as follows:

\begin{tabular}{|c|c|}
\hline \multicolumn{2}{|c|}{ Teachers' ICT Skills Gap on Use of ICT Integration in Teaching of [STEM Subjects] and Students' Performance } \\
\hline Study & Key findings \\
\hline Adom \& Aravind, 2019 & $\begin{array}{l}\text { Technology provides a platform through which programs can ask for a student's input, statistically analyze student inputs and } \\
\text { help clarify misconceptions or wrong ideas that students might sustain about a subject; teachers without technology skills fall } \\
\text { short of these benefits }\end{array}$ \\
\hline Lawrence and Tar (2018), & $\begin{array}{l}\text { Some of the barriers to lack of teacher ICT adoption as Lack of ICT knowledge, Lack of time, Resistance to change, } \\
\text { Complexity of integrating ICT, Limitation of infrastructure, Lack of training and Lack of technical support. }\end{array}$ \\
\hline $\begin{array}{l}\text { Gudmundsdottir and } \\
\text { Hatlevik (2018), }\end{array}$ & Teachers report fairly, poor quality and contribution of ICT training during their teacher education \\
\hline $\begin{array}{l}\text { Masingila, Khatete, } \\
\text { Maundu, Foley, Ndethiu } \\
\text { and Twoli (2019) }\end{array}$ & Found that few teachers who did not integrate IT in teaching had issues related to self-efficacy due to incompetence. \\
\hline $\begin{array}{l}\text { Chisango, Marongwe, Mtsi } \\
\text { and Matyedi (2020) }\end{array}$ & Teachers were ready to integrate ICTs in teaching and learning but they lacked the requisite ICT skills \\
\hline $\begin{array}{l}\text { Owen, Palekahelu, } \\
\text { Sumakul, Sekiyono and } \\
\text { White (2018) }\end{array}$ & Findings at a system level generally indicated insufficient coordination of teacher training and minimal follow-up occurring. \\
\hline $\begin{array}{l}\text { Tandika and Ndijuye } \\
\text { (2019) }\end{array}$ & $\begin{array}{l}\text { Teachers had variability in terms of knowledge and ICT skills integration in teaching; clear that a skills gap exists among } \\
\text { teachers. }\end{array}$ \\
\hline Bathgate et al., (2019) & $\begin{array}{l}\text { Pin points the need for a more powerful pedagogical design promoting technology-supported collaborative learning to } \\
\text { prepare learners for the twenty-first-century is crucial }\end{array}$ \\
\hline $\begin{array}{l}\text { (Joubert } \text { et al., 2018; } \\
\text { Tondeur, Krug, Bill, } \\
\text { Smulders, \& Zhu, 2015) }\end{array}$ & $\begin{array}{l}\text { prioritizes the provision of initial and ongoing in-service teacher education that effectively equips teachers to integrate ICT } \\
\text { into subject teaching and learning using contemporary pedagogical approaches; and a holistic and comprehensive framework } \\
\text { within and across East African countries to include infrastructure enhancement, development of ICT uses in schools and } \\
\text { large-scale professional development. }\end{array}$ \\
\hline Gap & $\begin{array}{l}\text { Need for a more powerful pedagogical design promoting technology-supported collaborative learning to prepare learners for } \\
\text { the twenty-first-century; STEM subjects have been purported to hold critical solutions to the } 21^{\text {st }} \text { Century society needs. }\end{array}$ \\
\hline
\end{tabular}


3.5. Teacher's plausible skills capacity interventions on the use of IT integration in the teaching of [STEM subjects] and influence on students' academic Performance

Examination of specific studies relevant capacity interventions on IT integration in Teaching of STEM subjects, portray that most of the studies were from Wiley online and Taylor and Francis which are quality research data bases. Table 4 and figure 5 demonstrate these results

Table 4

\begin{tabular}{ll}
\hline Data Base & No. of selected Article \\
\hline EMRALD & 40 \\
EBSCOhost & 35 \\
JSTOR & 5 \\
WILEY ONLINE & 180 \\
TAYLOR \& FRANCIS & 100 \\
\hline
\end{tabular}

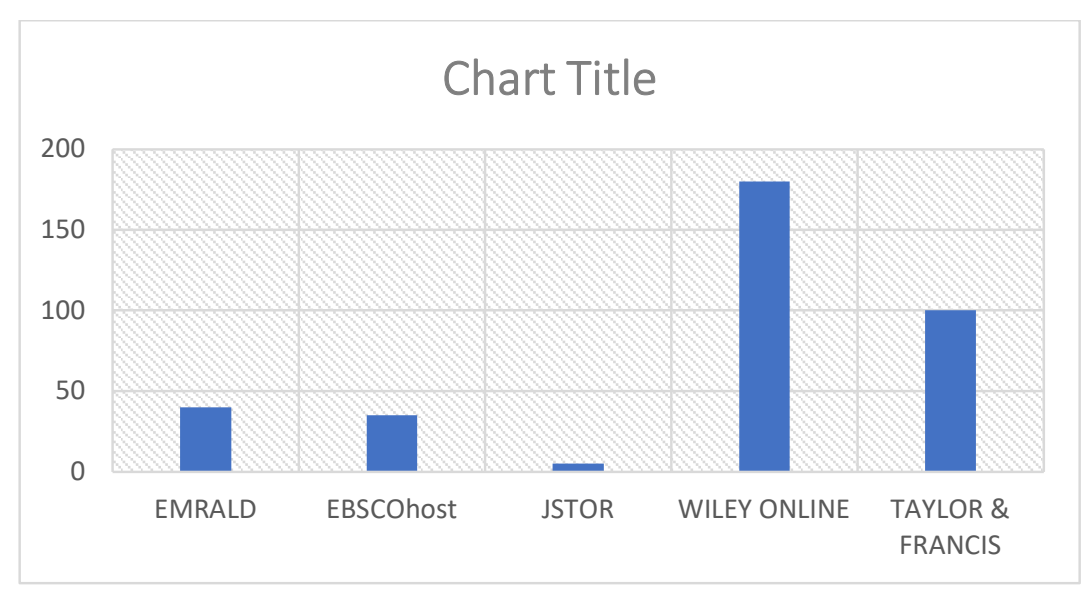

Figure 5

\section{Summary of Key Findings}

Some key studies illustrating key findings and ensuing study and intervention gaps were summarized as follows:

\begin{tabular}{|l|l|}
\hline \multicolumn{2}{|l|}{$\begin{array}{l}\text { Teachers' Plausible Skills Capacity Interventions on the Use of ICT Integration in the Teaching of [STEM } \\
\text { Subjects] and Student Performance }\end{array}$} \\
\hline Study & Key findings \\
\hline $\begin{array}{l}\text { Secretary, Affairs, \& Kariuki, } \\
2017\end{array}$ & $\begin{array}{l}\text {. Teachers as instructors need to develop STEM specific competences. STEM } \\
\text { competence covers both the 'know-what' (the knowledge, attitudes and values } \\
\text { associated with the disciplines) and the 'know-how' (the skills to apply that knowledge, } \\
\text { taking account of ethical attitudes and values in order to act appropriately and } \\
\text { effectively in a given context) }\end{array}$ \\
\hline Editor and Learning, (2019) & $\begin{array}{l}\text { Educators today are facing a major paradigm shift, in the form of the fourth industrial } \\
\text { revolution that requires a rapid response through Information }\end{array}$ \\
\hline $\begin{array}{l}\text { Daly, Pachler, \& Pelletier, } \\
2009\end{array}$ & $\begin{array}{l}\text { The teaching skills and pedagogy for STEM subjects requires continuous professional } \\
\text { development due to constant changes in knowledge content and dynamic technological } \\
\text { changes }\end{array}$ \\
\hline Capacity Interventions & $\begin{array}{l}\text { In-service training; provision of IT infrastructure in schools } \\
\text { MOE - Projects such as National interventions such as SMASE project at CEMASTEA, } \\
\text { INSET for primary school teachers have been avenues for teacher capacity building in } \\
\text { STEM subjects }\end{array}$ \\
\hline Gap & $\begin{array}{l}\text { Pedagogical and IT competencies have not been systematically ingrained in teacher } \\
\text { training institutes and at University education offerings. Robust research gap exists in } \\
\text { evaluation of interventions' impact on student academic performance. }\end{array}$ \\
\hline
\end{tabular}




\subsection{Teachers' access to IT in education on use of IT integration in the teaching of [STEM subjects] and influence on students' academic Performance}

Data collection from various databases on the teachers access to IT integration in teaching of STEM subjects was as follows:

Table 5

\begin{tabular}{ll}
\hline Data Base & No. of selected Articles \\
\hline EMRALD & 55 \\
EBSCOhost & 50 \\
JSTOR & 5 \\
WILEY ONLINE & 150 \\
TAYLOR \& FRANCIS & 180 \\
\hline
\end{tabular}

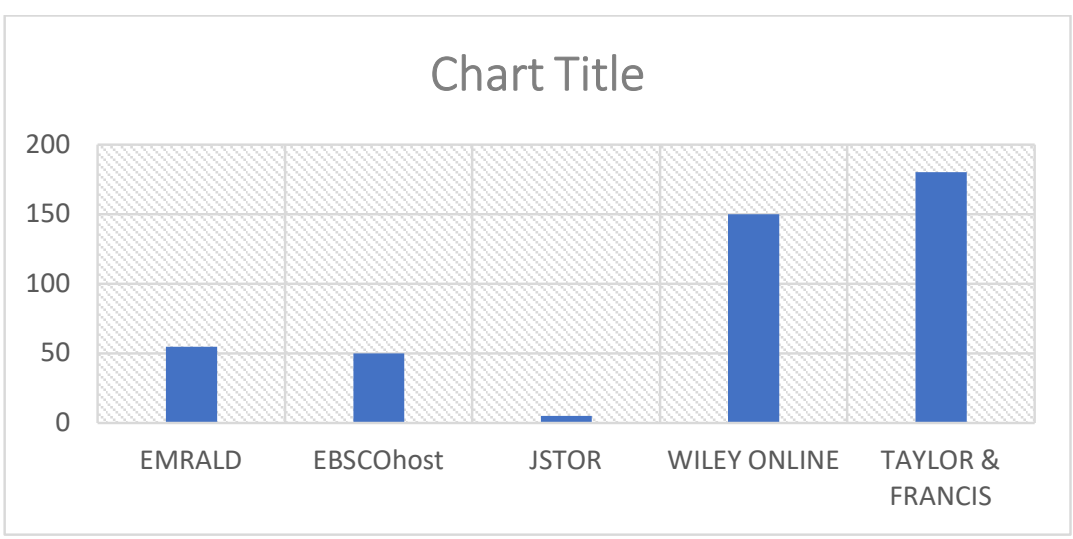

Figure 6

\section{Summary of Key Findings}

Some key studies illustrating key findings and ensuing study and intervention area gaps were summarized as follows:

\begin{tabular}{|c|c|}
\hline \multicolumn{2}{|c|}{$\begin{array}{l}\text { Teachers' Access to ICT in Education on Use of ICT Integration in the Teaching of [STEM Subjects] and Students } \\
\text { Performance }\end{array}$} \\
\hline Study & Key findings \\
\hline Mua Rodanny Kennah, 2017 & ICT can be used to remove communication barriers such as that of space and time \\
\hline Noor-Ul-Amin, 2013 & $\begin{array}{l}\text { ICTs also allow for the creation of digital resources like digital libraries where the } \\
\text { students, teachers and professionals can access research material and course }\end{array}$ \\
\hline $\begin{array}{l}\text { (Hooker, 2017);Noor-Ul- } \\
\text { Amin, 2013) }\end{array}$ & $\begin{array}{l}\text { ICT eliminates time barriers in education for learners as well as teacher. It eliminates } \\
\text { geographical barriers as learners can log on from any place }\end{array}$ \\
\hline $\begin{array}{l}\text { Jibrin, Musa, and Shittu, } \\
\text { (2017) }\end{array}$ & $\begin{array}{l}\text { The finding reveals that internet is one of the beneficial tools in this era of Information } \\
\text { and Communication Technology (ICT) used in academic exercise of which cannot be } \\
\text { accessed without appropriate ICT infrastructure }\end{array}$ \\
\hline Ghavifekr and Rosdy, (2015) & $\begin{array}{l}\text { Teachers' well-equipped preparation with ICT tools and facilities is one the main } \\
\text { barriers to success of technology-based teaching and learning }\end{array}$ \\
\hline Ishaq et al., (2020) & $\begin{array}{l}\text { Most if students and teachers in Pakstan had sufficient access to ICT tools such as } \\
\text { laptops, personal computers at their homes and computers at their universities, but the } \\
\text { printing, scanning facilities were less available at homes }\end{array}$ \\
\hline $\begin{array}{l}\text { Basri, Alandejani, and } \\
\text { Almadani, (2018) }\end{array}$ & $\begin{array}{l}\text { ICT access and adoption resulted in the improvement of the performance of female } \\
\text { students more than the male. }\end{array}$ \\
\hline Gap & $\begin{array}{l}\text { Teacher access to ICT Education in parts of the world, including Kenya is faced with } \\
\text { barrier related to Technology infrastructure, software and relevant teacher training } \\
\text { curriculum for STEM competencies }\end{array}$ \\
\hline
\end{tabular}




\subsection{Availability of digital content in the cloud on the use of IT integration in the teaching of [STEM subjects]} and influence on students' academic Performance

Data collection from various databases on availability of digital content in the cloud on use of IT integration in teaching of STEM subjects was as follows:

Table 6

\begin{tabular}{ll}
\hline Data Base & No. of selected Articles \\
\hline EMRALD & 35 \\
EBSCOhost & 15 \\
JSTOR & 10 \\
WILEY ONLINE & 85 \\
\hline TAYLOR \& FRANCIS & 155 \\
\hline
\end{tabular}

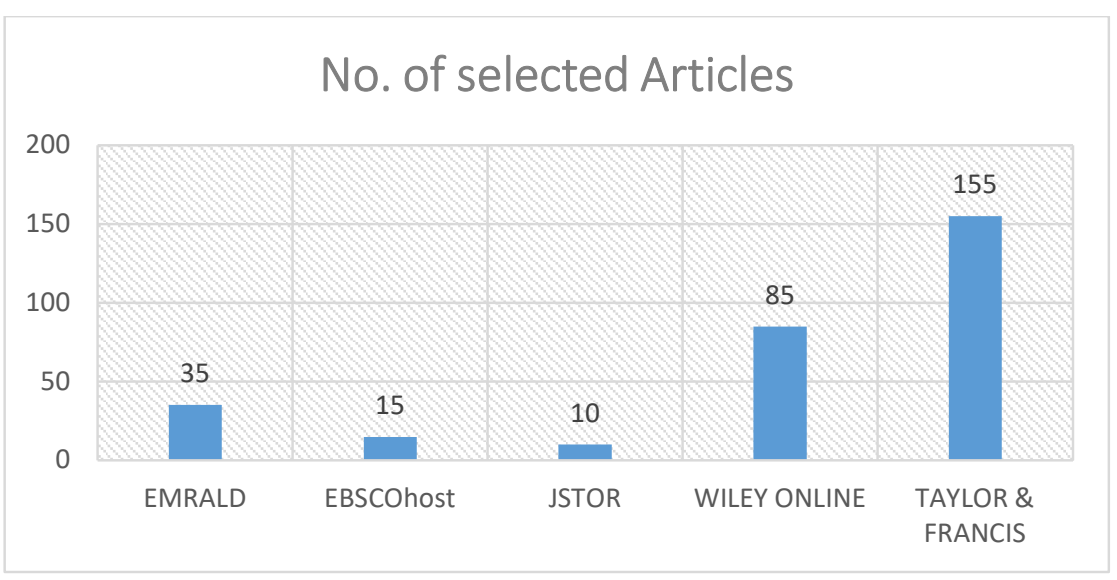

Figure 7

\section{Summary of Key Findings}

Some key studies illustrating key findings and ensuing study and intervention area gaps were summarized as follows:

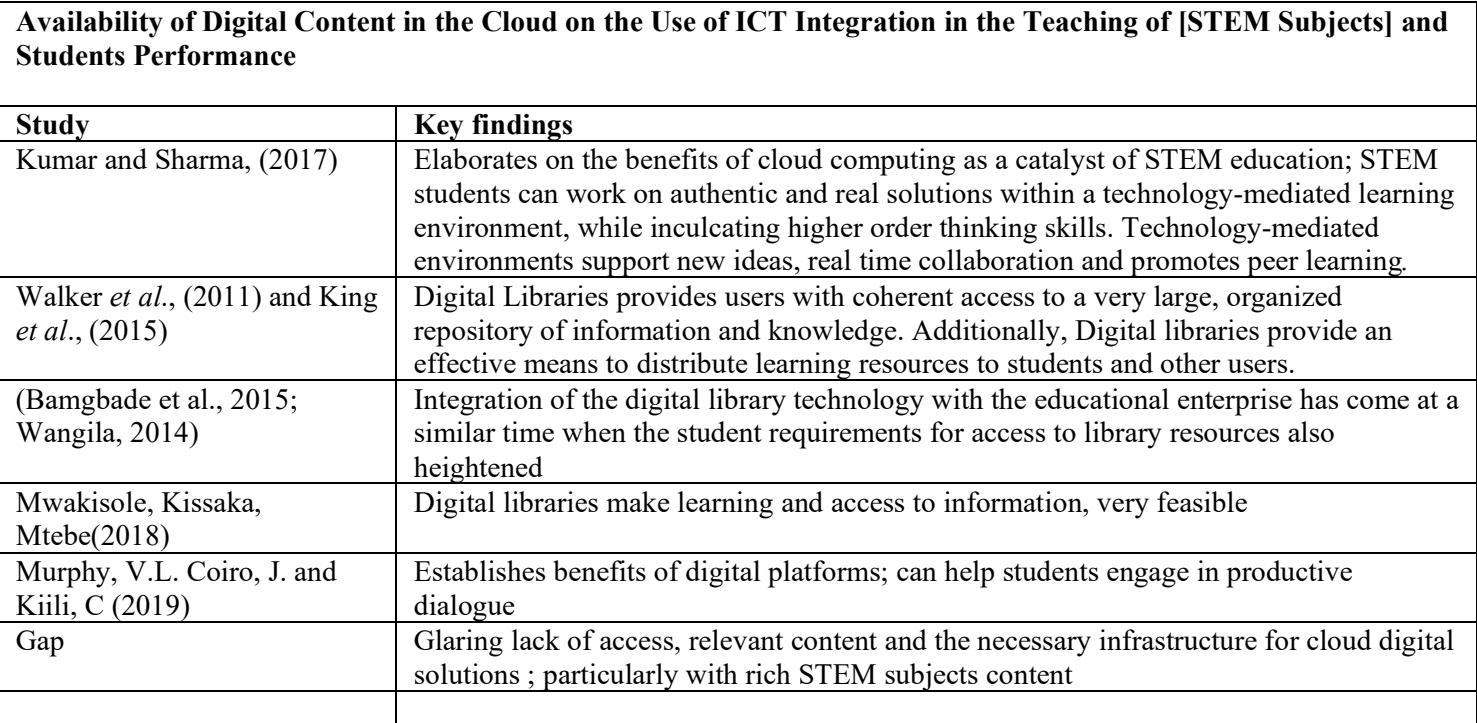

Although this study mainly focused on studies from the five key data bases, important contributions were also found scantly in other data bases such as: American Society for Information Science, Library Philosophy and 
Practice, Information Management journals and International Journal of Academic Research in Business and Social Science among others.

\section{DISCUSSION}

\subsection{Pedagogical Beliefs of Teachers on Use of ICT Integration in Teaching of [STEM Subjects] and Students Performance}

Pedagogical beliefs of teachers on use and integration of ICT in teaching of STEM subjects is likely to influence their perceptions and practice whereby negative beliefs may also negatively affect learners' education outcome (Eickelmann \& Vennemann, 2017) . Bell, (2016) in support of this proposition, asserted that teacher's perception of STEM, their personal knowledge, and understanding of that knowledge, is intrinsically linked to the effectiveness of STEM delivery in their own classroom practice. Bell, further pointed that in order for learners (pupils) to become STEM literate, teachers of all STEM subjects should be supported to explore ways in which they can best foster mutually reciprocal arrangements with their STEM counterparts. Additionally, (Margot \& Kettler, 2019)opines that for schools to include quality STEM education, it is important to understand teachers' beliefs and perceptions related to STEM talent development. The scholars purport that Teachers, as important persons within a student's talent development, hold prior views and experiences that will influence their STEM instruction. Their study findings in USA, indicate that while teachers value STEM education, they reported barriers such as pedagogical challenges, curriculum challenges, structural challenges, and concerns about students, concerns about assessments, and lack of teacher support.

On the other hand, (Polgampala \& Shen, 2016) in a study on Perceptions on STEM Education in Secondary Schools in Sri Lanka, determined that lack of methodology, strategies and technology were some of the teacher challenges in this study. It was also indicated that teachers with a strong capacity to teach in their discipline are essential for the success of STEM practices. (Madani \& Forawi, 2019) focused on Teacher Perceptions of the New Mathematics and Science Curriculum in Saudi Arabia and concluded that the new STEM curricula should attempt to make meaningful connection between student's lives and their educational experiences through the implementation of new teaching practices which include student centered investigation strategies and problembased learning. (Leem et al., 2019) in a study on Teachers' beliefs and technology acceptance concerning smart mobile devices for SMART education in South Korea posited that teachers' beliefs were consistently revealed the five factors of immediacy, interest, interactivity, instability and inconvenience. Regarding the effect of the technology acceptance of SMDs on teachers' beliefs, the factors of instability, inconvenience and interactivity strongly related to the perceived usefulness and ease of use of SMDs. This finding indicates that teachers' beliefs that SMDs are unstable or uncomfortable can be the main barrier to the use of technology in the classroom.

Kurup et al., (2019) on Building future primary teachers' capacity in STEM: based on a platform of beliefs, understandings and intentions, purported that STEM education needs to begin in primary schools and should aim to prepare young people for active participation in their future. To produce a generation interested and skilled in STEM, the key foci within schools may best occur through teams of teachers working together in an integrated approach, based on cross curricular teaching and learning. Teachers play a key role in STEM education, and it is important to attract high achievers with relevant backgrounds into teaching. Further, Kurup et al findings indicate that pre-service teachers do not have strong understanding; however, they have strong beliefs and intentions to teach STEM in their future career. However, this scholar recommends that it is essential to formulate a course work and professional development in STEM, capable of integrating disciplines, providing an understanding of pedagogical approaches, and connecting to real-life relevance with the twenty-first century competencies.

Tsai et al., (2019) explored the relationships among preservice teachers' conceptions of teaching using mobile devices and the quality of technology integration in lesson plans in Taiwan. The results showed that four qualitatively different conceptions of teaching using mobile devices namely "technology support," "knowledge transmission," "learning facilitation," and "supporting students to learn." This study also found that the teachers who had more constructivist perceptions of teaching using mobile devices, such as facilitating students' understanding in a convenient way or supporting student learning in a more active way, appeared to attain better quality technology integration in their lesson plans than those teachers with traditional conceptions.

Chisango, Marongwe, Mtsi and Matyedi (2020), focused on Teachers' Perceptions of Adopting Information and Communication Technologies in Teaching and Learning at Rural Secondary Schools in Eastern Cape, South Africa, Africa. The study found that the teachers had a positive attitude towards the adoption of technologies and were ready to integrate ICTs in teaching and learning but they lacked the requisite ICT skills. The article concludes 
that ICT is an important vehicle in education, and further recommends the training of both teachers and learners in ICT usage.

Deducing from various studies, it is clear that right from training to point of entry into teaching profession, teachers have beliefs and intentions to succeed; as such delayed training on relevant pedagogy for STEM subjects and IT integration may affect students' academic performance.

\subsection{Teachers' ICT Skills Gap on Use of ICT Integration in Teaching of [STEM Subjects] and Students' Performance}

Technology helps foster an interaction between teacher and students(Adom \& Aravind, 2019). As such, Technology provides a platform through which programs can ask for a student's input, statistically analyze student inputs and help clarify misconceptions or wrong ideas that students might sustain about a subject. On the one hand, technology allows teachers to experiment with pedagogical methods and analyze results to test their teaching effectiveness but in contrast, teachers argue that technology can be distracting and perhaps can make cheating easier in the classroom (Burbules \& Callister, 2018 in Adom \& Aravind, 2019).

To cater for learning in a broad variety of students, technology can be a useful pedagogical tool; with videos, animations and automated tutors, students can learn at their own pace. They are not to be constrained to the space of the classroom or time in a lecture hour (Means et al., 2009) Nowadays, learner experience - rather than learning materials - has become the main selling point. With the rise in artificial intelligence-based technologies, this trend is expected to continue the inclusion of testing and assessment in a timely manner with intelligent tutoring systems.

Lawrence \& Tar, (2018) pointed to some of the barriers to lack of teacher ICT adoption as Lack of ICT knowledge, Lack of time, Resistance to change, Complexity of integrating ICT, Limitation of infrastructure, Lack of training and Lack of technical support.

Gudmundsdottir \& Hatlevik, (2018) studied on Newly qualified teachers' professional digital competence among Norwegian student teachers. In general, newly qualified teachers report fairly, poor quality and contribution of ICT training during their teacher education. Thus, continuous effort is needed to review the quality of ITE and contribute specifically to the development of PDC and developing student teachers' ICT self-efficacy in ITE.

Masingila, Khatete, Maundu, Foley, Ndethiu and Twoli (2019) in a study on From Implementation to Efficacy: Factors Affecting Kenyan Secondary Teachers' Technology Integration; found that few teachers who did not integrate IT in teaching had issues related to self-efficacy due to incompetence.

On the other hand, (Owen et al., 2018) worked on Systematic educational change and teacher skill-building in developed and developing countries: the importance of teacher peer learning groups. Findings at a system level generally indicated insufficient coordination of training and minimal follow-up occurring. Ndijuye and Tandika, (2020) on teachers' preparedness in integrating information and communication technology in teaching and learning in Tanzania; study observes that teachers had variability in terms of knowledge and ICT skills integration in teaching; clear that a skills gap exists among teachers.

Bathgate et al., (2019) in a study on STEM Education challenges in Asia Pacific pin points that powerful pedagogical design promoting technology-supported collaborative learning to prepare learners for the twenty-firstcentury is crucial. Gardner, Joubert, Barrett and Tikly, (2018), identifies technology use as a strong approach to Strengthening Secondary STEM \& ICT Education in Sub-Saharan Africa. Further study by (Wilson, 2014) on Computer Usage among University Teacher-Trainees concluded that that teacher education programs need to provide teacher-trainees with further training programs to help them enhance their skills in the use of computers as an instructional tool for teaching and learning.

In a report on Developing the Use of Information and Communication Technology to Enhance Teaching and Learning in East African Schools, (Joubert et al., 2018; Tondeur, Krug, Bill, Smulders, \& Zhu, 2015) prioritizes the provision of initial and ongoing in-service teacher education that effectively equips teachers to integrate ICT into subject teaching and learning using contemporary pedagogical approaches; and a holistic and comprehensive framework within and across East African countries to include infrastructure enhancement, development of ICT use in schools and large-scale professional development.

The professional development of teachers involves developing the knowledge and skills of teachers in educational technology for them to be able to impart students with the ultimate goal of making technology instruction in the 
classrooms more engaging and interesting (Means et al., 2009) Many teachers cannot integrate technology effectively in teaching and learning processes (Kauffman, Ge, Xie, \& Chen, 2008).

Glaringly, observations from various studies show that a skills gap exists among teachers across continents in terms of ICT skills and integration in their teaching pedagogy; more so teacher training does not keenly focus on computer skills and especially those related to STEM teaching. Logically, it follows that teachers with lack of technology skills in $21^{\text {st }}$ Century are likely to impact negatively on learner achievement.

\subsection{Teachers' Plausible Skills Capacity Interventions on the Use of ICT Integration in the Teaching of [STEM Subjects] and Student Performance}

Capacity building and skills development are integral to harnessing the transformative potential of the ongoing development and increasing sophistication of information and communication technologies (ICT) (Cosmas Zavazava, Susan Teltscher, Mike Nxele \& Stankovska-Castilla, Letamo, 2018) In the digital era, the demands of the typical student in higher education include the use of ICT in teaching methods, flexible timing and location to complete studies, and real world applicability of courses. Such demands lead to pressure on universities and other higher learning institutions to introduce new processes and resources, while teachers may be expected to modify teaching methods in the absence of any additional training. However, the content of effective capacity building programs requires frequent re-evaluation, as new ICT trends and technologies now appear over ever shorter timeperiods. New challenges for these programs have been presented by the appearance of next generation networks (NGNs), IPv6, cloud computing, the Internet of Things (IoT), big data and Artificial Intelligence (AI). Toni Janevski provides an overview of these challenges, in addition to an examination of the implications of important associated issues such as Quality of Service (QoS) and cybersecurity.

Boon, (2010) report on Exploring STEM Competences for the 21st Century, points that effective STEM subject teaching would be a major response to the United Nations' 2030 agenda for sustainable Development. Education, and particularly Science, Technology, Engineering and Mathematics (STEM) education, plays a crucial role in achieving the SDGs (Kennedy \& Odell, 2014) alludes to the need for capacity building in STEM literacy among stakeholders. Such literacy entails:

- Knowledge, attitudes, skills [and values] to identify questions and problems in life situations. Explain the natural and designed world, and draw evidence-based conclusions about STEM related issues;

- Understanding of the characteristic features of STEM disciplines as forms of human knowledge, inquiry, and design;

- Awareness of how STEM disciplines shape our material, intellectual, and cultural environments; and

- Willingness to engage in STEM-related issues with the ideas of science, technology, engineering, and mathematics as a constructive, concerned and reflective citizen.

In a fast-changing world, with technology evolving at an unprecedented pace, competence is conceptualized as a developmental capacity rather than as a set of fixed skills (Burkhalter et al., 1984); (Marope et al., 2017) Based on these definitions, STEM competence refers to an individual's ability to apply STEM knowledge, skills and attitude appropriately in his or her everyday life, workplace or educational context. Teachers as instructors need to develop STEM specific competences. STEM competence covers both the 'know-what' (the knowledge, attitudes and values associated with the disciplines) and the 'know-how' (the skills to apply that knowledge, taking account of ethical attitudes and values in order to act appropriately and effectively in a given context) (Secretary et al., 2017)

Editor and Learning, (2019) propose that a smart pedagogy for digital transformation, where artificial intelligence will provide smart educational agents, needs to consider how technologies affect perceptions of reality, cognition, and social interactions. Educators today are facing a major paradigm shift, in the form of the fourth industrial revolution that requires a rapid response through Information. New technologies and infrastructures enable learning to be personalized to each individual learner

In Kenya, Capacity Building for Teachers is done through Continuous Professional Development (CPD) in order to improve the quality of Education. This is a planned and lifelong process whereby teachers try to develop their professional and personal qualities and to improve their knowledge, skills and practice leading to their empowerment, improvement of their organization and their learners. Effective teaching requires considerable knowledge and skills which should be developed as a teacher's career progresses. The teaching skills and pedagogy for STEM subjects requires continuous professional development due to constant changes in knowledge content and dynamic technological changes (Daly et al., 2009) National interventions such as SMASE project at CEMASTEA, INSET for primary school teachers have been avenues for teacher capacity building in STEM subjects; however pedagogical competencies have not been systematically ingrained in teacher training institutes 
and at University education offerings . Robust research gap exists in evaluation of interventions' impact on student academic performance. Generally, pedagogy in STEM subjects has glaring aforementioned research gaps of which this study endeavors to bridge particularly in Kenya's' context; and with ultimate goal to bring forth capacity building intervention through teacher training in pedagogy for STEM subjects.

\subsection{Teachers' Access to ICT in Education on Use of ICT Integration in the Teaching of [STEM Subjects] and Students Performance}

Information communication technology (ICT) is among the latest innovations that has revolutionized various operations in the world. It is particularly important in the field of education since it has recently created such platforms and opportunities that have facilitated to some extent the acquisition of knowledge and teachers and learners. The use of ICT in education lends itself to more student-centered learning settings and as the world moves rapidly into digital media and information, the role of ICT in education is becoming more and more important. ICT increases the flexibility of delivery of education so that learners and teachers can access knowledge anytime and from anywhere. ICTs are said to help expand access to education, strengthen the relevance of education to the increasingly digital workplace, and raise educational quality. The direct link between teachers ICT use and students' academic performance has been in research focus, with justifications that ICT helps in improving the communication between learners and the instructors (Ishaq et al., 2020)

Generally, people have to access knowledge via ICT to keep pace with the latest developments (Mua Rodanny Kennah, 2017) ICT can be used to remove communication barriers such as that of space and time (Lim and Chai, 2004). ICTs also allow for the creation of digital resources like digital libraries where the students, teachers and professionals can access research material and course(Noor-Ul-Amin, 2013) Such facilities allow the networking of academics and researchers and hence sharing of scholarly material. ICT eliminates time barriers in education for learners as well as teacher. It eliminates geographical barriers as learners can log on from any place (; (Hooker, 2017);Noor-Ul-Amin, 2013).

Jibrin, Musa, and Shittu, (2017) investigated effects of internet on the academic performance of students in tertiary institutions within Niger state, Nigeria. The finding reveals that internet is one of the beneficial tools in this era of Information and Communication Technology (ICT) used in academic exercise of which cannot be accessed without appropriate ICT infrastructure. The study also revealed some of the problems encountered in the usage of internet which include slow internet speed and lack of stable power supply. Ghavifekr and Rosdy, (2015) studied teaching and learning with Technology and Effectiveness of ICT Integration in Schools. Findings indicate that teachers' well-equipped preparation with ICT tools and facilities is one the main factors in success of technologybased teaching and learning. It was also found that professional development training programs for teachers also played a key role in enhancing students' quality learning.

Ishaq et al., (2020) in a study on The Impact of ICT on Students' Academic Performance in Public Private Sector Universities of Pakistan concluded that most of the respondents had sufficient availability of ICT tool, i.e. laptops, personal computers at their homes and computers at their universities, but the printing, scanning facilities were less available at homes but these facilities could be availed from the university. The majority of the students in claiming that they used ICT to perform different tasks, such as preparing assignments, classroom activities and plan their lessons more efficiently. Basri, Alandejani, and Almadani, (2018) focused on ICT Adoption Impact on Students' Academic Performance: Evidence from Saudi Universities. The study also examined the moderators' effect of gender, GPA, and student majors on the relationship between ICT and academic achievement. The findings reveal that there exists a relationship between ICT adoption and academic performance in a conservative environment. An additional finding also stated that ICT adoption resulted in the improvement of the performance of female students more than the male.

On the contrary, ICT access is not an obvious key to academic performance. Karamti, (2016) focused on Measuring the Impact of ICTs on Academic Performance: Evidence from Higher Education in Tunisia. Using survey data involving 377 college students and teachers, a multilevel analysis was conducted to measure the impact of ICT access and use with other student, university, and teacher attributes that may affect academic performance. The results provided evidence for a distinctive, though negative, effect of ICT on performance. These findings raise questions about the effectiveness of educational policies in Tunisia. The findings suggest also that overall university support is essential in increasing ICT learning impacts.

Across divides, studies demonstrate that ICT access is necessary for technology integration in education, particularly benefits rest in teacher's improvement of practice as well as student democracy in exploration of knowledge and information. As such, ICT access has been related to good academic performance in different 
studies with a few contrary results; therefore, this study will test if technology access influences teacher integration of ICT in practice and its effect on student performance in Kenya.

\subsection{Availability of Digital Content in the Cloud on the Use of ICT Integration in the Teaching of [STEM} Subjects] and Students Performance

In $21^{\text {st }}$ Century, emerging digital content repositories and cloud storage of information has made teaching and learning materials not only more accessible but also available to a wide range of users in variety of modes. Kumar and Sharma, (2017) concurs that Technology integration in curriculum makes it more interesting and engaging, where students can learn with flexibility in time and place. Kumar further elaborates on the benefits of cloud computing as a catalyst of STEM education: -

This methodology creates and deepens interest in students towards learning with creativity and innovation. STEM students can work on authentic and real solutions within a technology-mediated learning environment, while inculcating higher order thinking skills. Technology-mediated environments support new ideas, real time collaboration and promotes peer learning. However, affordance as an adoption factor of technology in academics can be addressed by cloud computing technology. STEM education on cloud computing technology will gain access to its content rich features based on flexibility, accessibility, scalability, affordability, and reliability and enhanced agility. The cloud computing based STEM education infrastructure inculcate development and experimentation skills in students.

Walker et al., (2011) and King et al., (2015) concurs that, "digital Libraries provides users with coherent access to a very large, organized repository of information and knowledge. Additionally, Digital libraries provide an effective means to distribute learning resources to students and other users. Planning a digital library requires thoughtful analysis of the organization and its users, and an acknowledgement of the cost and the need for infrastructure and ongoing maintenance for continued access (Bamgbade et al., 2015; Wangila, 2014). Wangila, asserts that the integration of the digital library technology with the educational enterprise has come at a similar time when the student requirements for access to library resources also heightened. The development of policies, guidelines and standards has been a common practice in libraries to ensure professional efficiency and quality of information service.

Nazim, (2009) purports that the most important component of digital library is its digital collection. Viability and extent of usefulness of a digital library would depend upon the critical mass of its digital content. The information content of a digital library includes virtually any kind of electronic media (text, image, graphic, video, etc.) licensed database of journals, articles and abstracts and description of physical collection. Thus, this rich variety in content and in formats have propensity to catalyze increased use of digital libraries among teachers and students, a move that is likely to boost academic performance.

In a nutshell, from discussed literature, there are undisputed extra benefits of using digital content and embracing cloud computing for storage and preservation which makes information accessible anytime anywhere and even simultaneous use by multiple users. Such benefits can be ploughed into STEM subject teaching; teachers in professional training and development can access rich content to continuously up skill. On the alternate teachers who use old "yellow" notes are likely to deliver obsolete information to learners who in turn perform dismally.

\section{CONCLUSION}

This systematic literature review unravels gaps indeed exist in terms of Digital library characteristics; Digital library access, Digital library subscription costs; Digital library variety in content; Digital library availability of content and how these variables influence extensive reading culture.

Technically lack of technology gadgets, connectivity, lack of awareness on use of digital libraries intervene against the goal of extensive reading culture.

Additional gaps alienated include the cost of subscription to content sources, as well as limitation in skill of service providers. More so, the distrust based on copyright management as well as plagiarism trends.

Limitations also exist in terms of availability of variety of content as well as the linkage between different user needs in different contexts of the world.

\section{RECOMMENDATION}

Clearly, from the study results, it can be concluded that there is need to carry out comprehensive empirical study to test actual influence of the Digital library characteristics on extensive reading outcomes in the society. Chow 
and Sajonas, (2019); suggest use of People-Centered research methods to improve the public Library Experience. Levine-Clark, (2019) project on collaborative approach to content collection while O'Gara and Osterman, (2019)advice on use of Collective Power of the Consortium to transform the Journal Subscription Model as a way to reduce cost on journal subscriptions.

This literature review recommends further studies to explore more digital library characteristics and specific reading outcomes in different contexts. More so, intervention measures such as capacity building among librarians, different users of digital libraries would be of necessity. In situations of infrastructural challenges such as relevant gadgets to host the digital libraries, interventions in provisions of these gadgets would make digital library content access more practical.

\section{LIMITATIONS}

The research process acknowledges the databases used and articles perused may not be hundred per cent representative of all factors and constructs relevant for the study. However, the results resonate with practical experiences on the ground, and reasonably provide useful information for future interventions.

\section{REFERENCES}

Adom, D., \& Aravind, V. R. (2019). Application of Educational Technology to Teaching and Learning in the 20th Application of Educational Technology to Teaching and Learning in the 20 th and 21 st Centuries Educator Perceptions of Technology Integration. December, 40-53.

Alexander, R. (2009). University of Cambridge TOWARDS A COMPARATIVE PEDAGOGY. International Handbook of Comparative Education, 923-942. https://www.robinalexander.org.uk/wp-content/uploads/2012/05/IHCE-chapter59-Alexander.pdf

Bamgbade, B. J., Akintola, B. A., Agbenu, D. O., Ayeni, C. O., Fagbami, O. O., \& Abubakar, H. O. (2015). Comparative analysis and benefits of digital library over traditional library. Wsn, 24(2015), 1-7. www.worldscientificnews.com

Barakabitze, A. A., William-Andey Lazaro, A., Ainea, N., Mkwizu, M. H., Maziku, H., Matofali, A. X., Iddi, A., \& Sanga, C. (2019a). Transforming African Education Systems in Science, Technology, Engineering, and Mathematics (STEM) Using ICTs: Challenges and Opportunities. Education Research International, 2019(February). https://doi.org/10.1155/2019/6946809

Barakabitze, A. A., William-Andey Lazaro, A., Ainea, N., Mkwizu, M. H., Maziku, H., Matofali, A. X., Iddi, A., \& Sanga, C. (2019b). Transforming African Education Systems in Science, Technology, Engineering, and Mathematics (STEM) Using ICTs: Challenges and Opportunities. Education Research International, 2019. https://doi.org/10.1155/2019/6946809

Basri, W. S., Alandejani, J. A., \& Almadani, F. M. (2018). ICT Adoption Impact on Students' Academic Performance: Evidence from Saudi Universities. Education Research International, 2018. https://doi.org/10.1155/2018/1240197

Bathgate, M. E., Aragón, O. R., Cavanagh, A. J., Waterhouse, J. K., Frederick, J., \& Graham, M. J. (2019). Perceived supports and evidence-based teaching in college STEM. International Journal of STEM Education, 6(1). https://doi.org/10.1186/s40594-019-0166-3

Bell, D. (2016). The reality of STEM education, design and technology teachers' perceptions: a phenomenographic study. International Journal of Technology and Design Education, 26(1), 61-79. https://doi.org/10.1007/s10798-0159300-9

Bhowmik, M., Roy, B. B., \& Banerjee, J. (2013). Role of Pedagogy in Effective Teaching. Basic Research Journal of Education Research and Review, 2(1), 1-5.

Boon, S. (2010). Exploring STEM Competences for the 21 st Century. 30, 1-53. https://pdfs.semanticscholar.org/55f1/bff79642ca16d1054ef78f16cbb2b1b83234.pdf

Burkhalter, B. B., Sharpe, M. R., Halpin, G. M., Schaer, B. B., Curtis, J. P., \& Wallace, W. H. (1984). Education for the Future. Space Education, 1(7), 290-295.

Chow, L., \& Sajonas, S. (2019). From UX Study to UX Service: Using People-Centered Research Methods to Improve the Public Library Experience. Public Library Quarterly, 00(00), 1-17. https://doi.org/10.1080/01616846.2019.1682884

Cosmas Zavazava, Susan Teltscher, Mike Nxele, H., \& Stankovska-Castilla, Letamo, and E. (2018). Capacity Building in a Changing ICT Environment. https://doi.org/http://handle.itu.int/11.1002/pub/80f4831e-en

Daly, C., Pachler, N., \& Pelletier, C. (2009). Continuing Professional Development in ICT for teachers : A literature review Caroline Daly Norbert Pachler WLE Centre, Institute of Education, University of London Contents. WLE Centre, Institute of Education, University of London, June.

Durodolu, O. O., \& Mojapelo, S. M. (2020). Contextualisation of the information literacy environment in the South African 
education sector. Electronic Journal of E-Learning, 18(1), 57-68. https://doi.org/10.34190/EJEL.20.18.1.005

Editor, L. D., \& Learning, E. (2019). Didactics of Smart Pedagogy. In Didactics of Smart Pedagogy. https://doi.org/10.1007/978-3-030-01551-0

Eickelmann, B., \& Vennemann, M. (2017). Teachers' attitudes and beliefs regarding ICT in teaching and learning in European countries. European Educational Research Journal, 16(6), 733-761. https://doi.org/10.1177/1474904117725899

Gardner, V., Joubert, M., Barrett, A. M., \& Tikly, L. (2018). Approaches to Strengthening Secondary STEM \& ICT Education in Sub-Saharan Africa. Bristol Working Paper in Education Series, March, 94.

Ghavifekr, S., \& Rosdy, W. A. W. (2015). Teaching and learning with technology: Effectiveness of ICT integration in schools. International Journal of Research in Education and Science, 1(2), 175-191. https://doi.org/10.21890/ijres.23596

Gorder, L. M. (2008). A study of teacher perceptions of instructional technology integration in the classroom. Delta Pi Epsilon, L(2 Spring/Summer), 63-76.

Grasia Chisango, Newlin Marongwe, Nomxolisi Mtsi \& Thembisile E. Matyedi (2020) Teachers' Perceptions of Adopting Information and Communication Technologies in Teaching and Learning at Rural Secondary Schools in Eastern Cape, South Africa, Africa Education Review, 17:2, 1-19, DOI: 10.1080/18146627.2018.1491317

Gudmundsdottir, G. B., \& Hatlevik, O. E. (2018). Newly qualified teachers' professional digital competence: implications for teacher education. European Journal of Teacher Education, 41(2), 214-231. https://doi.org/10.1080/02619768.2017.1416085

Guler, G., Sen, C., Ay, Z. S., \& Ciltas, A. (2019). Engineering skills that emerge during model-eliciting activities (MEAs) based on 3D modeling done with mathematics pre-service teachers. International Journal of Education in Mathematics, Science and Technology, 7(3), 251-270.

Hennessy, S., Onguko, B., Harrison, D., Kiforo, E., Namalefe, S., \& Naseem, A. (2010). Developing the Use of Information and Communication Technology to Enhance Teaching and Learning in East African Schools: Review of the Literature. Africa, May, 121. http://www.educ.cam.ac.uk/centres/cce/publications/CCE_Report1_LitRevJune0210.pdf

Hooker, M. (2017). A Study on the Implementation of the Strengthening Innovation and Practice in Secondary Education Initiative for the preparation of Science, Technology, English and Mathematics (STEM) Teachers in Kenya to integrate Information and Communication Technology. Queen's University Belfast, May.

Hunter, J. (2017). Switching Middle School Teachers onto STEM Using a Pedagogical Framework for Technology Integration: The Case for High Possibility Classrooms in Australia. Research Highlights in Technology and Teacher Education 2017, January 2017, 37-46.

Ishaq, K., Azan, N., Zin, M., Rosdi, F., Abid, A., \& Ijaz, M. (2020). The Impact of ICT on Students' Academic Performance in Public Private Sector Universities of Pakistan. International Journal of Innovative Technology and Exploring Engineering, 9(3), 1117-1121. https://doi.org/10.35940/ijitee.c8093.019320

Joanna O. Masingila, David W. Khatete, John N. Maundu, Alan R. Foley, Sophia M. Ndethiu \& Nicholas W. Twoli (2019) From Implementation to Efficacy: Factors Affecting Kenyan Secondary Teachers' Technology Integration, Africa Education Review, 16:1, 58-87, DOI: 10.1080/18146627.2016.1224574

Jibrin, M. A., Musa, M. N., \& Shittu, T. (2017). Effect of internet on the academic performance of tertiary institutions' students in Niger State, Nigeria. International Journal of Education, Learning and Training, 2(2), 57-69. https://doi.org/24924/ijelt/2017.04/v2.iss2/57.69

Joubert, M., Barrett, A. M., Tikly, L., Joubert, M., Angeline, M., Bainton, D., \& Cameron, L. (2018). Secondary School STEM Education for Sustainable Development in Africa Professor Leon Tikly Dr Dave Bainton Leanne Cameron Supporting Secondary School STEM Education for Sustainable Development in Africa.

Karamti, C. (2016). Measuring the Impact of ICTs on Academic Performance: Evidence From Higher Education in Tunisia. Journal of Research on Technology in Education, 48(4), 322-337. https://doi.org/10.1080/15391523.2016.1215176

Kauffman, D. F., Ge, X., Xie, K., \& Chen, C. H. (2008). Prompting in web-based environments: Supporting self-monitoring and problem solving skills in college students. Journal of Educational Computing Research, 38(2), 115-137. https://doi.org/10.2190/EC.38.2.a

Kennedy, T. J., \& Odell, M. R. L. (2014). Engaging Students In STEM Education. Science Education International, 25(3), $246-258$.

Kilty, K. M. (1978). Attitudinal and normative variables as predictors of drinking behavior. Journal of Studies on Alcohol, 39(7), 1178-1194. https://doi.org/10.15288/jsa.1978.39.1178

King, N., Ma, T. H.-Y., Zaphiris, P., Petrie, H., Hamilton, F., \& Trivedi, M. (2015). DigitalCommons @ University of Nebraska - Lincoln Digital Libraries : Functionality, Usability, and Accessibility. Libraries Without Walls 5, May 2010, 123-131. https://doi.org/10.29085/9781856047876.012 
Kumar, V., \& Sharma, D. (2017). Cloud computing as a catalyst in STEM education. International Journal of Information and Communication Technology Education, 13(2), 38-51. https://doi.org/10.4018/IJICTE.2017040104

Kurup, P. M., Li, X., Powell, G., \& Brown, M. (2019). Building future primary teachers' capacity in STEM: based on a platform of beliefs, understandings and intentions. International Journal of STEM Education, 6(1). https://doi.org/10.1186/s40594-019-0164-5

Lawrence, J. E., \& Tar, U. A. (2018). Factors that influence teachers' adoption and integration of ICT in teaching/learning process. Educational Media International, 55(1), 79-105. https://doi.org/10.1080/09523987.2018.1439712

Levine-Clark, M. (2019). Imagining the Future Academic Library Collection. Collection Management, 44(2-4), 87-94. https://doi.org/10.1080/01462679.2019.1610680

Madani, R. A., \& Forawi, S. (2019). Teacher Perceptions of the New Mathematics and Science Curriculum: A Step Toward STEM Implementation in Saudi Arabia. Journal of Education and Learning, 8(3), 202. https://doi.org/10.5539/jel.v8n3p202

Maluleke, M. J. (2019). Using code-switching as an empowerment strategy in teaching mathematics to learners with limited proficiency in English in South African schools. South African Journal of Education, 39(3), 1-9. https://doi.org/10.15700/saje.v39n3a1528

Margot, K. C., \& Kettler, T. (2019). Teachers' perception of STEM integration and education: a systematic literature review. International Journal of STEM Education, 6(1). https://doi.org/10.1186/s40594-018-0151-2

Marope, M., Griffin, P., \& Gallagher, C. (2017). Future competences and the future of curriculum:a global reference for curricula transformation. International Bureau of Education, 1-60.

Means, B., Toyama, Y., Murphy, R., Bakia, M., \& Jones, K. (2009). Evaluation of Evidence-Based Practices in Online Learning. Structure, 66.

Miller, J., \& Khera, O. (2010). Digital Library Adoption and the Technology Acceptance Model: A Cross-Country Analysis. The Electronic Journal of Information Systems in Developing Countries, 40(1), 1-19. https://doi.org/10.1002/j.1681-4835.2010.tb00288.x

Mua Rodanny Kennah. (2017). The Use of ICT in the Teaching and Learning Process in Secondary Schools. August, 1-75.

N, A. L., Dzakpasu, P. E., \& Amenyedzi, K. D. (2019). Principals 'ICT Proficiency Level and Tutors 'Willingness to Adopt Modern Technological Devices in Teaching in the Volta and Greater Accra Regions, Ghana. 50(August). https://doi.org/10.12691/ajis-7-1-1

Nazim, M. (2009). Managing Digital Library Content: Issues and Challenges. SRELS Journal of Information Management, 46(1), 29-35. http://search.ebscohost.com/login.aspx?direct=true\&db=1xh\&AN=37613283\&site=ehostlive \&scope $=$ site

Ndijuye, L. G., \& Tandika, P. B. (2020). STEM starts early: Views and beliefs of early childhood education stakeholders in Tanzania. Journal of Childhood, Education \& Society, 1(1), 29-42. https://doi.org/10.37291/2717638x.20201128

Ndiku, J., Aurah, C., Okoth, T., Ogenga, P., \& Ongus, E. (2020). Baseline survey report on status of teaching and learning of STEM subjects and English Language in pilot secondary schools in Kakamega, Vihiga and Kisumu counties, Kenya. March.

Noor-Ul-Amin, S. (2013). An Effective use of ICT for Education and Learning by Drawing on Worldwide Knowledge, Research, and Experience : ICT as a Change Agent for Education. Department Of Education University of Kashmir, 1(1), 1-13. https://doi.org/6th August 2016

O'Gara, G., \& Osterman, A. C. (2019). Negotiating on Our Terms: Harnessing the Collective Power of the Consortium to Transform the Journal Subscription Model. Collection Management, 44(2-4), 176-194. https://doi.org/10.1080/01462679.2018.1564716

Ochich, P., Barasa, I., Otieno, I., Karicho, C., Atamba, A., Ngie, P., Maswai, P., \& Gioko, K. (2018). THE KENYA NATIONAL To be a world class leader in educational assessment and certification To assess abilit ies and certify learner achievements in conformit y wit h global standards. June, 1-48.

Owen, S., Palekahelu, D., Sumakul, T., Sekiyono, E., \& White, G. (2018). Systematic educational change and teacher skillbuilding in developed and developing countries: the importance of teacher peer learning groups. Teacher Development, 22(4), 447-463. https://doi.org/10.1080/13664530.2017.1403370

Polgampala A.S.V, \& Shen, H. (2016). Perceptions on STEM Education in Secondary Schools in Sri Lanka : Trends and Challenges. 12, 301-306.

Sarrab, M. (2015). M-learning in Education: Omani Undergraduate Students Perspective. Procedia - Social and Behavioral Sciences, 176, 834-839. https://doi.org/10.1016/j.sbspro.2015.01.547

Secretary, E. C., Affairs, G., \& Kariuki, S. (2017). Strengthening STEM education in Kenya. June, 30-31.

Tahir, M., \& Yucel, S. (2019). Motivational Techniques for Teaching: Prophetic Model. International Journal of Teaching \& Education, VII(2), 1-12. https://doi.org/10.20472/te.2019.7.2.006

Tondeur, J., Krug, D., Bill, M., Smulders, M., \& Zhu, C. (2015). Integrating ICT in Kenyan secondary schools: an 
exploratory case study of a professional development programme. Technology, Pedagogy and Education, 24(5), 565-584. https://doi.org/10.1080/1475939X.2015.1091786

Tsai, Y. S., Poquet, O., Gašević, D., Dawson, S., \& Pardo, A. (2019). Complexity leadership in learning analytics: Drivers, challenges and opportunities. British Journal of Educational Technology, 50(6), 2839-2854. https://doi.org/10.1111/bjet.12846

Ullah, M. A., Alam, M. M., Shan-A-Alahi, A., Rahman, M. M., Masum, A. K. M., \& Akter, N. (2019). Impact of ICT on students' Academic performance: Applying association rule mining and Structured Equation modeling. International Journal of Advanced Computer Science and Applications, 10(8), 387-393. https://doi.org/10.14569/ijacsa.2019.0100852

Walker, P. D., Cammy, N. E., Ellis, B. J., \& Seibert, K. D. (2011). O Perations S Kills F or the 21 St C Entury. 10, 1-16.

Wangila, F. (2014). An Assessment of the Implementation of Digital Library Technologies in Institutions of Higher Learning: A Case Study of Kenyatta University. International Journal of Academic Research in Business and Social Sciences, 4(9), 532-541. https://doi.org/10.6007/ijarbss/v4-i9/1176

Wilson, K. B. (2014). Computer usage among university teacher-trainees. US-China Education Review A, 4(6), 387-394. 